\title{
The Effect of Instruction in Pragmatics: Compliments \& Compliment Responses
}

\author{
Zia Tajeddin \\ Allameh Tabataba'i University, Iran \\ Email: Zia_tajeddin@yahoo.com \\ Mohammad Reza Ghamari \\ Allameh Tabataba'i University, Iran \\ Email: dr_m_rezaghamary2@yahoo.com
}

\begin{abstract}
Researchers claim that learners benefit from instruction in compliments and compliment responses in a foreign language context (Ishihara 2003a, 2011; Billmyer 1991). Others have found that a narrow range of syntactic formulas accounted for the majority of observed compliments. This study tries to investigate the learnability of compliments in a formal foreign language context. Also, attempt is made to find whether the formulas obtained lend support to the Asian model of preference for acceptance or rejection strategy as far as compliments and compliment responses are concerned. 40 female students participated in the study and an 18item metapragmatic assessment questionnaire was administered. The results were examined through a t-test providing some evidence that instruction in pragmatics can make a positive difference in a formal context. Farsi-speaking female students using preference for acceptance strategy, cast doubt on the existence of any sort of strict dichotomy, but claiming that it's a matter of continuum.
\end{abstract}

Index Terms—pragmatics, compliments, compliment response, questionnaire, foreign language, instruction

\section{INTRODUCTION}

This article offers the results of a study on the effects of instruction in pragmatics, with the target features being compliments and compliment responses.

Pragmatics is a framework for understanding language use. Focusing on the role of context, O'Keeffe, et al. (2011) hold that there are many means of arriving at a pragmatic understanding of language, ranging from the analysis of texts to philosophical debate.

They assert that the teaching of pragmatics is important for two reasons: "(1) It has been demonstrated that there is a need for it; and (2) quite simply it has proven to be effective" (O'Keeffe, et al., 2011, p.38). In Takimoto's study (2009) those who received instruction concerning polite requests, outperformed the control group.

Research on compliments and compliment responses is largely traced back to the work of Nessa Wolfson and Joan Manes (Wolfson \& Manes, 1980; Manes \& Wolfson, 1980; Wolfson, 1981a; 1981b; Manes, 1983), which provided the first comprehensive description of the formulaicity of compliments in American English. They found that a narrow range of syntactic formulas accounted for the majority of observed compliments.

An excellent study on compliments and compliment responses conducted by Miles (1994) provides a useful synthesis of existing categories for compliment responses which was the starting point for this study. These categories include acceptance (e.g. Thanks), deflect, (e.g., Anyone can do this), rejection, (e.g., No, it's not really that nice), and no response.

An interesting issue in compliment responses research is that of potential differences across cultures. In the case of compliment responses, several studies which have found a preference for rejecting compliments in Chinese contexts are relevant for this study because this preference would appear to run counter to the prevailing view of the American preference of accepting compliments.

For example, in a study of the compliment responses of native speakers (NSs) of American English and NSs of Mandarin Chinese, Chen (1993) found an overwhelming preference for rejection for the latter (19.73\%), while the former employed this option far less frequently (12.7\%). In responding to compliments, Americans tended to accept compliments or justify or extend them; Japanese questioned their accuracy, denied them, and explained the reason why they were not deserved, or responded by smiling or saying nothing at all. The closer the relationship was, the more frequently Americans gave compliments especially on appearances, while Japanese were less likely to offer praise. Female speakers in both cultures were more likely to give and receive compliments (Barnlund \& Araki, 1985).

\section{RESEARCH QUESTIONS}

Two major questions are going to be addressed in this study. 
1. Do learning compliments and compliment responses occur in a FL context? In other words, are compliments and compliment responses teachable?

2. Does the study come up with results that lend support to the Asian preferences for accepting, or rejecting compliments?

\section{REVIEW OF LITERATURE}

Chung-hye (1992) comparing the compliment responses of ten Korean females in English interactions and in Korean interactions, with 10 American females, found that Korean females responded differently when speaking in Korean and English, with little evidence of pragmatic transfer. In Korean, the respondents mostly rejected the compliments (45\%), deflecting or evading them in $35 \%$ of the cases, and accepting them only in $20 \%$. In English, there was $75 \%$ acceptance with only $20 \%$ rejection.

Creese (1991) looks at how cultural differences are reflected in five speech acts of the Americans and the Britons: requesting, thanking, apologizing, complimenting, and greeting, paying attention to lexical predictability, compliment responses, syntactic categories, and compliment topic.

In a study done by Daikuhara (1986), ninety-five percent of all responses to compliments fell into the 'self-praise avoidance' category, which included rejection of the compliment (35\%), smile or no response (27\%), and questioning (13\%).

Billmyer (1991) conducted a study investigating the effect of instruction on the performance of compliments by two groups of adult Japanese females studying English-as-a-second-language at the University of Pennsylvania. Instruction was shown to have positive effects for learners on five out of seven measures of performance.

Furukawa (2000) illustrates through examples that compliments reflect not only sociocultural values but also personal values and standards, and defines the compliment in consideration of the recipient of the compliment and closeness and status of the interlocutors. Furukawa (2001) believes that compliments directed at someone who is of higher status are considered a face-threatening act in Japanese, yet native speakers use a number of strategies to retain respect and politeness while realizing the act.

Ishihara (2011) introduces classroom instruction on giving and responding to compliments for intermediate ESL learners. In her previous study (2003a), the results had led to the findings indicating that instruction probably facilitated learners' improvement not only in terms of giving but responding to compliments.

The instruction facilitates learners' outside-of-class observation and interaction with other speakers of English. Class discussions encourage learners to consider various situational factors and compare American compliments with those in their native languages, sensitizing them to appropriate use of language and cultural differences. In the study, Ishihara (2003a) explores immediate and delayed effects of formal instruction on giving and responding to compliments in an ESL classroom setting. The instruction, given to 31 intermediate adult ESL learners, facilitated their out-of-class observation and interaction. The results of the analyses lend support to the positive effects of formal instruction in pragmatics reported in previous studies.

The response strategies in the data obtained by Koike (2000) from 326 native speaking subjects were examined separately for interpersonal variables, generations, and gender. The author also came up with her own categorization based on past studies (acceptance, rejection, and neural responses, and sub-strategies in each). Subjects in their 30's tended to either express thanks (25\%), or reject the compliment and offer humble comments (44\%), while those in their 60 's mostly responded favorably, often accepting the compliment.

In the above study, gender played a considerable role. Women used rejection, humble comments, and thanks more often than men, while men responded proudly, showing a sense of power and dominancy, or expressed shyness more than women.

Lorenzo-Dus (2001) examined a corpus of over 1000 tokens of compliment responses in British English and Peninsular Spanish in terms of cross-cultural and gender differences. The analysis of the outcome revealed crosscultural and gender differences.

Rose and Kwai-fun (2001) compared the effects of inductive and deductive approaches to the teaching of English compliments and compliment responses to university-level learners of English in Hong Kong. Results for compliment responses revealed a positive effect only for the deductive group, indicating that although inductive and deductive instruction may both lead to gains in pragmalinguistic proficiency, only the latter may be effective for developing sociopragmatic proficiency.

Using 901 responses to compliments from TV talk shows and authentic conversations, Teroa (1996) focuses on characteristics of compliment responses in Japanese. Compared to Holme (1986) (although the taxonomy is slightly different) where acceptance types occurred $60 \%$ of the times, acceptance was found less than a third (30\%). Rejection was used much more frequently in Japanese (25\%) than in English (10\%). By drawing examples and analyzing some lexical items, the researcher points out that even in acceptance types in Japanese, there were humble comments that speakers offered. Speakers also used various other semantic strategies to avoid self-praise and admiration for their family members (e.g., offering negative comments and perspectives).

Rose and Kwoi-fun (2001) point out that more research is needed before any conclusions can be reached concerning cultural preferences for compliment responses, and not all existing studies have found a preference for rejection among 
"Asians". They believe that there is conflicting evidence on "Asian" preferences for compliment responses, with several studies indicating some degree of preference for compliment rejection (p.147).

The rationale for examining the effects of instruction in pragmatics is underscored by Schmidt's (1993) contention that simple exposure to the target language is insufficient (Kasper \& Rose, 2002). The results of a growing body of interventional pragmatics studies, according to Kasper \& Rose (2002) strongly suggest that most aspects of L2 pragmatics are indeed teachable, that instructional intervention is more beneficial than no instruction specifically targeted on pragmatics, and that for the most part, explicit instruction combined with ample practice opportunities results in the greatest gains.

Therefore, in the present study attempt has been made to collect data concerning native speakers of Farsi, as far as and compliment responses are concerned.

This study also tries to examine the effects of instruction in compliments and compliment responses. Bilmyer (1990a, 1990b) was among the first to study the effects of instruction in compliments, finding that although there was an advantage for the instructed group, her participants were able to learn how to compliment in American English with or without instruction.

Bilmyer's learners benefited from the acquisition-rich ESL environment in which they lived. This feature is a key factor in a number of studies on the effects of instruction in pragmatics. The question is whether results similar to those obtained in SL environment would obtain in an FL context.

\section{Methodology}

\section{A. Subjects}

The samples taking part in this study included 40 female students studying at police women academy with the average age of 21.60. The participants were chosen randomly and were assigned to two groups, control and experimental. Rose and Kwai-fun (2001) point out that research has indicated that gender is an important variable in the use of compliments and compliment responses, so the gender disparity across groups will have to be taken into consideration in interpreting results.

\section{B. Instrument}

A metepragmatic assessment questionnaire (MAQ) was used in this study to address the research questions. It contained 18 scenarios according to which the subjects were to choose the correct one out of the four possible compliment responses provided. The answers included a dichotomy: a preference for acceptance or a preference for rejection.

To collect data concerning the subjects' reaction to the compliments offered and to prevent any probable misunderstanding of the scenarios described, also, a translated version of the questionnaire and more explanation about the environment of the situations was given to the subjects.

A pre-test was assigned to both groups, followed by a five-week instruction only for the experimental group.

Then, a post-test was used for both groups. In this stage, in view of any possible misunderstanding of the scenarios described, a translated version of the questionnaire was given to the subjects. More explanation about the environment of the situations was given orally by the researcher.

\section{Data Collection}

Although Kasper and Roever (2005) note that all questionnaire types, including DCTs, probe into "offline selfreporting states of knowledge or beliefs, multiple choice studies which probe situational routines and implicatures were found to have a satisfactory degree of consistency" (O'Keeffe, et al., 2011, p.27). So, an 18-item questionnaire, containing a scenario for each, was administered. Each scenario was followed by a compliment. For each compliment, 4 kinds of possible compliment responses were given as you might see in a multiple choice test. The participants were asked to choose the correct one out of the four responses. Every correct response scored one with a maximum of 18 . An obvious problem here is just what counts as a "correct" response. One way to determine correctness, according to Rose and Kwai-fun (2001), is to simply consider the response of the majority of NSs the "correct response", which is what, was done here. While there are potential problems with this approach, it's the fact that U.S. group scored near perfect (17.47).

Two intact classes took part in this study, each of which was randomly assigned to one experimental group and one control group. The control group received no treatment, but took part in both pre-test and post-test during the same time periods as the experimental group.

The experimental group received instruction in compliments and compliment responses that consisted of 4 lessons lasting for approximately 30 minutes each. Instruction began in week 4 of the semester and continued through week 8 .

\section{Data Analysis}

Participants were asked to choose among the four possible responses to a compliment, provided for a described scenario. These responses belonged to either of the two major compliment response strategies -preference foe 
acceptance or preference for rejection- along with the option of saying nothing at all, that is opting out. The data that this instrument yields can be analyzed differently. The way which was treated in this study appears not to be complex.

The metepragmatic assessment questionnaire (MAQ) essentially was treated as a compliment response test, allocating one point for each correct response. The mean of correct response were computed for the two groups during pre-tests and during post-tests. The obtained results were compared as displayed in table1.-5. Examining the means of responses for each group reveals some interesting similarities and differences.

To analyze the MAQ, the means for the 2 groups for both pre-test and post-test were computed and compared. To do so, McNamar test was utilized. Table 3 displays the results of MAQ pretest and post test.

\section{E. Results}

The two questions motivating the present study provided us with the following results. In order to see whether the two groups of subjects were homogeneous and evaluate the performance of the participants in the two groups, an independent t-test was conducted on their means performances. Table1 shows the results of the t-test in which sig. (.598) was higher than .05 , which means that there is no significant difference between the two groups.

TABLE 1

INDEPENDENT SAMPLE T-TESTS BETWEEN CONTROL AND EXPERIMENTAL GROUPS

Independent Samples Test

\begin{tabular}{|c|c|c|c|c|c|c|c|c|c|c|}
\hline & \multicolumn{2}{|c|}{$\begin{array}{l}\text { Levene's Test for } \\
\text { Equality of Variances }\end{array}$} & \multicolumn{7}{|c|}{ t-test for Equality of Means } \\
\hline & & \multirow[b]{2}{*}{$\mathrm{F}$} & \multirow[b]{2}{*}{ Sig. } & \multirow[b]{2}{*}{$t$} & \multirow[b]{2}{*}{$d f$} & \multirow[b]{2}{*}{ Sig. (2-tailed) } & \multirow{2}{*}{$\begin{array}{c}\text { Mean } \\
\text { Difference }\end{array}$} & \multirow{2}{*}{$\begin{array}{l}\text { Std. Error } \\
\text { Difference }\end{array}$} & \multicolumn{2}{|c|}{$\begin{array}{l}95 \% \text { C onfidence } \\
\text { Interval of the } \\
\text { Difference }\end{array}$} \\
\hline & & & & & & & & & Lower & Upper \\
\hline PriTest & $\begin{array}{l}\text { Equal variances } \\
\text { assumed }\end{array}$ & 4.754 & .035 & .532 & 38 & .598 & .55000 & 1.03409 & -1.54341 & 2.64341 \\
\hline & $\begin{array}{l}\text { Equal variances } \\
\text { not assumed }\end{array}$ & & & .532 & 32.968 & .598 & .55000 & 1.03409 & -1.55395 & 2.65395 \\
\hline
\end{tabular}

A paired sample test was administered for both groups to see if there was any change between the performances of the participants in experimental group during pre-test and post test. As table 2 and 3 show, there was a significant difference (sig=.007) between the means obtained by participants in experimental group during pre-test and post test. Lower and upper intervals appear negative, proving a positive effect for the variable employed. Accordingly, the assumed null hypothesis for the first question of the study, no relationship between instruction and learning pragmatics, is rejected

TABLE 2.

THE MEANS OF EXPERIMENTAL GROUP DURING PRE-TEST AND POST TEST Paired Samples Statistics

\begin{tabular}{|ll|r|r|r|r|}
\hline & & & & & \\
& & Mean & $N$ & Std. Deviation & $\begin{array}{c}\text { Std Eror } \\
\text { Mean }\end{array}$ \\
\hline Pair & PriTestEx & 8.6500 & 20 & 3.85630 & .86229 \\
1 & PostTestEx & 12.3000 & 20 & 3.58506 & .80164 \\
\hline
\end{tabular}

TABLE 3

COMPARING THE MEANS OF EXPERIMENTAL GROUP DURING PRE-TEST AND POST TEST Paired Samples Test

\begin{tabular}{|c|c|c|c|c|c|c|c|c|}
\hline & \multicolumn{5}{|c|}{ Paired Differences } & \multirow[b]{3}{*}{$t$} & \multirow[b]{3}{*}{ df } & \multirow[b]{3}{*}{ Sig. (2-tailed) } \\
\hline & \multirow[b]{2}{*}{ Mean } & \multirow[b]{2}{*}{ Std. Deviation } & \multirow{2}{*}{$\begin{array}{l}\text { Std. Error } \\
\text { Mean }\end{array}$} & \multicolumn{2}{|c|}{$\begin{array}{l}95 \% \text { Confidence } \\
\text { Interval of the } \\
\text { Difference }\end{array}$} & & & \\
\hline & & & & Lower & Upper & & & \\
\hline Pair1 $\quad$ PriTestEx-PostTestEx & -3.65000 & 5.45098 & 1.21888 & -6.20114 & -1.09886 & -2.995 & 19 & .007 \\
\hline
\end{tabular}

Meanwhile, a paired sample test was administered to evaluate any probable change for the control group; no significant difference was seen. Tables 4 and 5present the results of the paired sample test for control group during pretest and post test. Sig. (.419) appears more than .05 showing no significant difference.

TABLE 4.

THE MEANS OF CONTROL GROUP DURING PRE-TEST AND POST TEST

Paired Samples Statistics

\begin{tabular}{|ll|r|r|r|c|}
\hline & & Mean & $N$ & Std. Deviation & $\begin{array}{c}\text { Std. Error } \\
\text { Mean }\end{array}$ \\
\hline Pair & PriTestCtl & 8.1000 & 20 & 2.55260 & .57078 \\
1 & PostTestCtl & 7.9500 & 20 & 2.16370 & .48382 \\
\hline
\end{tabular}


TABLE 5.

COMPARING THE MEANS OF CONTROL GROUP DURING PRE-TEST AND POST TEST

Paired Samples Test

\begin{tabular}{|c|c|c|c|c|c|c|c|c|}
\hline & \multicolumn{5}{|c|}{ Paired Differences } & \multirow[b]{3}{*}{$t$} & \multirow[b]{3}{*}{$\mathrm{df}$} & \multirow[b]{3}{*}{ Sig. (2-tailed) } \\
\hline & \multirow[b]{2}{*}{ Mean } & \multirow[b]{2}{*}{ Std. Deviation } & \multirow{2}{*}{$\begin{array}{l}\text { Std. Error } \\
\text { Mean }\end{array}$} & \multicolumn{2}{|c|}{$\begin{array}{l}95 \% \text { C onfidence } \\
\text { Interval of the } \\
\text { Difference }\end{array}$} & & & \\
\hline & & & & Lower & Upper & & & \\
\hline Pair1 $\quad$ PriTestCtl - PostTestCtl & .15000 & .81273 & .18173 & -.23037 & .53037 & .825 & 19 & .419 \\
\hline
\end{tabular}

The means of the correct response of compliment responses as presented in the above tables, states that the participants in the present study show a tendency toward acceptance of the compliments.

The results of the overall means of participants' performances in the four tests, pre-test and post test for control group ( 8.10 and 7.95 respectively) and pre-test for experimental group (8.65) show that they, as female Farsi-speaking students lend support to the preference for acceptance strategy. The low means obtained show that this tendency is not strict.

\section{DISCUSSION AND CONCLUSION}

This study set out to answer two questions. The first question concerned whether learners benefited from instruction in compliments and compliment responses in a foreign language context. The second sought to determine whether Farsi-speaking subjects as speakers of an Asian language use the preference rejection strategy or preference acceptance strategy regarding compliment responses. The results revealed that the female students of this study made use of instruction in learning pragmalinguistics. Also, the participants of this study showed a tendency toward the preference for acceptance strategy, which Asian cultures, Chinese and Japanese, have not tended in previous researches such as Chen (1993).

In sum, this study has provided some evidence that instruction in pragmatics can make a difference in a foreign language context. Also, the results from MAQ (metapragmatic assessment questionnaire) show that Farsi-speaking female students use preference for acceptance strategy. Accordingly, I might conclude that the answer to the second question, based on the overall results especially before any teaching intervention, would support the preference acceptance strategy, rejecting any sort of strict dichotomy. One could not believe in the existence of two specific poles, either mere acceptance or mere rejection of compliment responses. Rather it's a matter of a continuum, confirming the theories recognizing acceptance, inflection and rejection. The results, although, add some evidence to one side of the continuum, they do not reject the other side.

The marked increase in the use of preference for acceptance strategy regarding the experimental group, with no similar increase for the control group, indicates that instruction had a positive effect.

Since it has been proved that gender effect has a significant role in compliment response studies, it could be argued that the results of this study are limited to female Farsi-speaking learners and further research is needed to take male subjects into consideration.

\section{APPENDIX 1}

\section{Unit 1 Teaching Compliments and Compliment responses}

\section{Lesson 1: Teaching Compliments}

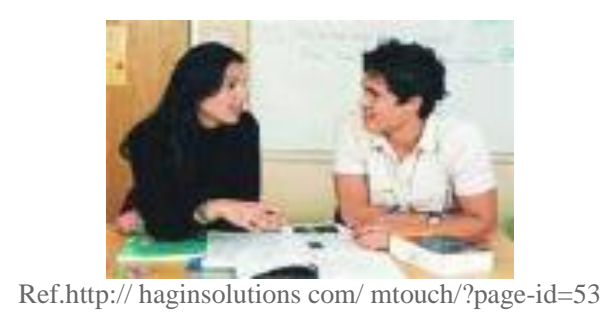

\section{Warm up.}

When you meet a friend or a relative, it's better to show your feeling if there is a new product, idea or activity.

The purpose of this lesson is to engage students in an activity where compliments are given and received and to discuss the feelings that arise from both situations.

Questionnaire about compliments and compliment responses

Think about compliments that you have given to somebody recently.

1. What were you talking about?

2. Who were you talking to?

3. How well do you know him? 

a. very well
b. not very well
c. not at all
4. What was your relationship to the person?
a. a friend
b. a teacher
c. a relative
5. How serious was the compliment?
a. very serious b. serious
c. not serious
6. What was your situation?
a. home
b. work place
c, street
7. How did you answer the compliment?
a. very polite
b, polite
c. rude
\# define "compliments" by giving a compliment to another student.
\# state how they felt when giving and receiving a compliment.
\# complete a paper plate face showing how their face looked when giving and receiving a compliment.

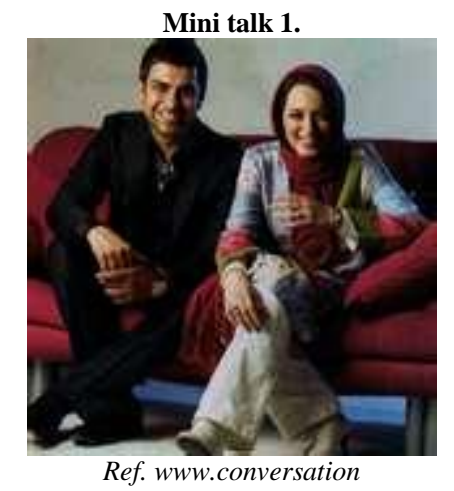

\section{Listen to the conversation}

Marie: You're really fit, Paul. Do you exercise very much?

Paul: Well, I almost always get up very early, and I lift weights for an hour.

Marie: You're kidding!

Paul: No. And then I often go Rollerblading.

(Ref. New interchange,1997 p.35)

Answer the following questions based on the above conversation.

1. What is the topic of this conversation?
a. lift weights
b. exercise
c. shop

2. What is the relationship of speakers?
a. teacher-student
b. friends
c. child-parent

3. What did Marie compliment Paulr on?

$\begin{array}{lll}\text { a. the shoes } & \text { b. green color } \quad \text { c. physical appearance }\end{array}$

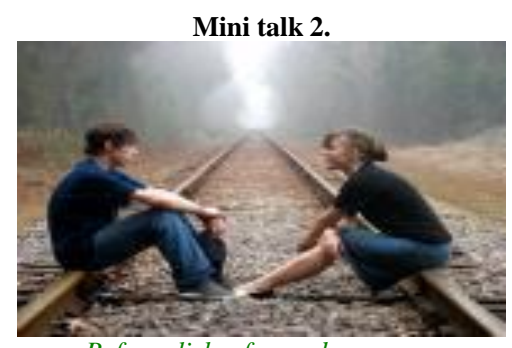

Ref. englishcafe.wordpress.com

Listen to this short conversation and answer the following questions.

Helen has got 20 in physics.

John: Your physics is great.

Helen: Thanks lot.

1. What was the adjective used in the compliment?

2. Did Helen accept it or reject it?

3. What's your probable answer in the situation?

\section{Lesson 2. Teaching Compliment responses}

It really is very nice. 


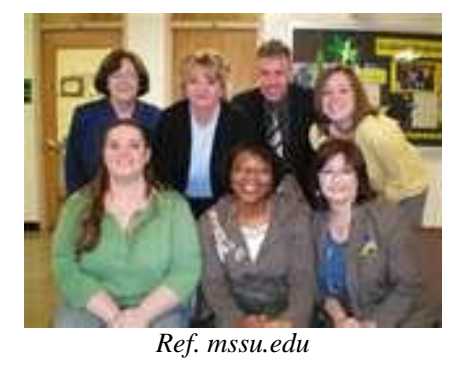

Listen to the following conversation.

\section{$\mathrm{A} \& \mathbf{C}=$ daughters}

\section{$B=$ mother}

A: That's a nice sweater, mom.

B: Thanks.

$\mathrm{C}$ : It really is very nice. Where did you get it?

B: I got it at Second Time Around in exchange for the red bag.

A: Oh, you got rid of the red bag?

B: Yeah, well, what else was I going to do with it?

A: But it was a gift from Jean.

B: I know, but that's okay, she wouldn't mind. We're used it enough.

C: Speaking of Jean, how's she doing, I wonder. We haven't heard from her much these days, have we?

B: No, not much, which doesn't surprise me, since she's gone on a whale-watching tour off the coast. She must be traveling in Canada by now.

$\mathrm{C}$ : Oh, really? I never knew that! How did I miss such news?

A: You never knew that? Oh, that's right! You were out of town on business the last time she stopped by. Now was it when you were in New York Chicago?

Answer the following questions based on the above conversation.

1. What is the conversation about?

2. Who got the sweater?

3. Where did the mother get it

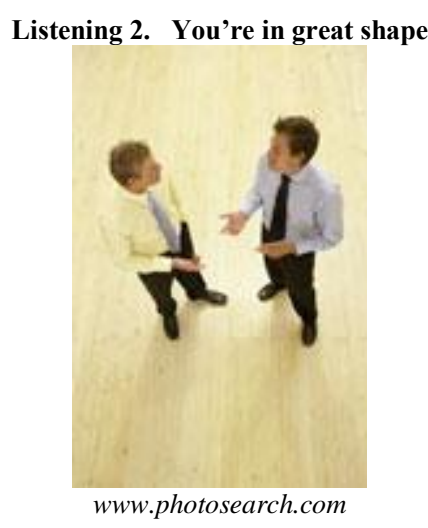

Listen to the following dialogue.

Rod: You're in great shape, Keith.

Keith: Thanks. I guess I'm a real fitness freak.

Rod: How often do you work out?

Keith: Well, I do aerobics twice a week. And then I play racquetball.

Rod: Say, I like racquetball, too.

Keith: Oh, do you want to play sometime?

Rod: Uh, ... how well do you play?

Keith: Pretty well, I guess.

Rod: Well, all right. But I'm not very good.

Keith: No problem, Rod. I won't play too hard.

Ref. New interchange 1997, p. 37.

Answer the following questions based on the above conversation:

1. Who is in a good shape?

2. What was Keith's reaction to the compliment?

3. What did Rod say? 


\section{Lesson 3. Top 6 Compliment Formulas}

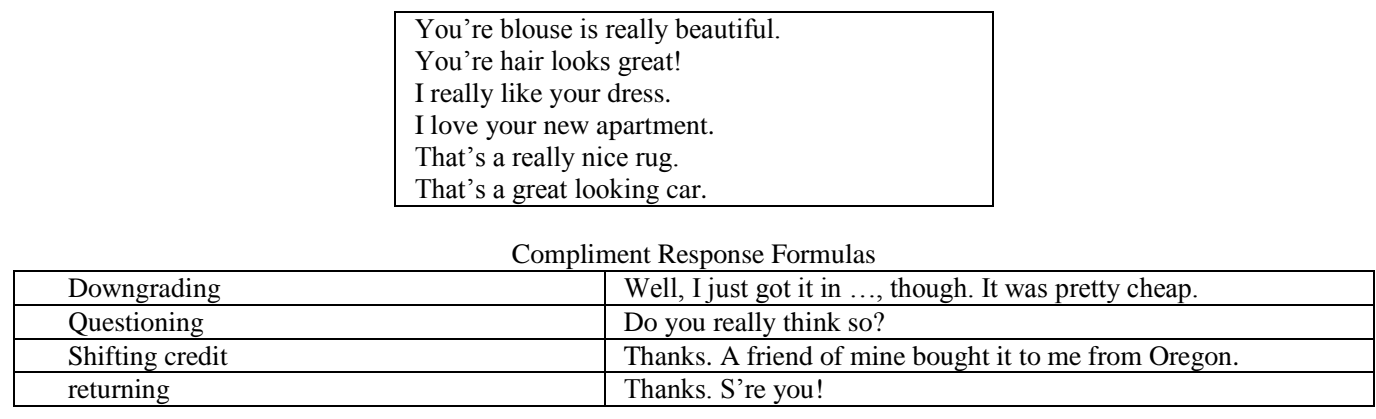

\section{Phrases and words used to offer compliments}

It's usual to pay attention to the feelings of others by offering a compliment.

\section{Example:}

Two businessmen are talking after a meeting.

BM1. I thought you did a great job in the meeting just now, John. Your report was very well-done.

BM2. Thanks a lot. I was pretty nervous, though.

Fill in the blanks using appropriate phrase or word in the following dialogue.

Mary: That's a really .... tie you have on tonight. I like it.

John: Thank you. I think you ..... really nice tonight, too.

Mary: Do you think so? This is wonderful place. How did you ever find it?

John: A friend of recommended it. I've been here a couple of times before. It has a ...... atmosphere.

Mary: I agree. I must compliment you on your ...... taste.

Clarify the offering compliments in the following sentences and put a checkmark next to each.

Your apartment is fantastic.

What a beautiful garden!

Thank you.

How nice you look tonight!

Do you think so?

I'd like to compliment you on your report.

Don't give me that.

\section{Lesson 4. Phrases and words used in compliment responses}

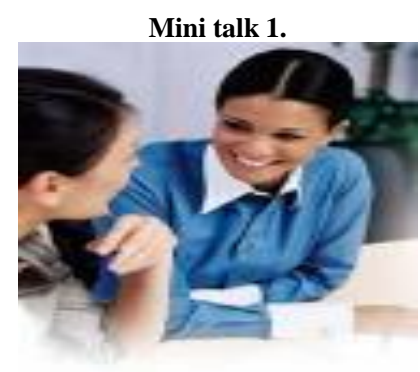

\section{Listen to the conversation}

Jennifer has already recently bought a pair of shoes.

Sara: Your shoes are really beautiful.

Jennifer: Thanks. I love green shoes.

Sara: Where did you get them?

Jennifer: From the shop next to the post office.

Answer the following questions based on the above conversation.

1 . What is the topic of this conversation?
a. post office
b. shoes
c. shop

2. What is the relationship of speakers?
a. teacher-student
b. friends
c. child-parent

3. What did Sara compliment Jennifer on?
a. the shoes
b. green color
c. shop

Phrases and words

Example: A young man is talking with the clerk at a driving center. 
C. Can I help you?

YM: Yes, I want to get a driver's licencse.

C. O.K. Fill out this form and bring it back to me here.

YM. Yes, ma'am. (Later) Here it is, Ma'am.

C. O.K. Let me see ... O.K. Everything looks fine...

YM. Wow! You have really nice handwriting

C. Don't try to flatter me, young man. Flattery will get you no where.

YM. I'm not trying to flatter you; I honestly think it's nice ....

A compliment may be accepted or rejected

Clarify whether the following statements accept or reject a compliment.

Thank you.

Don't give me that.

I don't like flatterers.

Nonsense.

Do you think so?

Oh, they're really not very good.

Thank you for the compliment.

Oh, it was nothing.

\section{Discourse completion tasks}

\section{Situation 1.}

You are at the university, and class has just ended. Your teacher overhears you answering your classmate's questions about how to use the computer. She tells you that you are good with computers.

You say:

\section{Situation 2.}

You have just finished having dinner at home that was prepared by `Mrs. White (the mother). You compliment her on the meal.

She says:

\section{Situation 3.}

You are at university, and class has just finished. While you are putting your books away, your teacher notices your new backpack and says that she or he likes it.

You say:

\section{Communicative Activities}

Based on the situations described provide appropriate phrase or word.

1. You are at a party. A friend has just finished singing a song.

You: You've got a nice voice.

Your friend:

2. A husband and wife are playing golf together! The wife hits a long-iron shot that lands two feet from the pin.

Husband: It was great.

Wife:

3. You are going out for dinner with a friend. He/she is very dressed up and looks very nice.

You:

Friend: Thanks a lot.

\section{Points to consider}

\#People feel good when they are told nice things about themselves.

\# The desired behaviour is giving specific compliments such as "Susan, you make beautiful pictures" rather than "you are nice."

\#Compliment a student, than ask others to give a compliment to the student.

\section{APPENDIX 2}

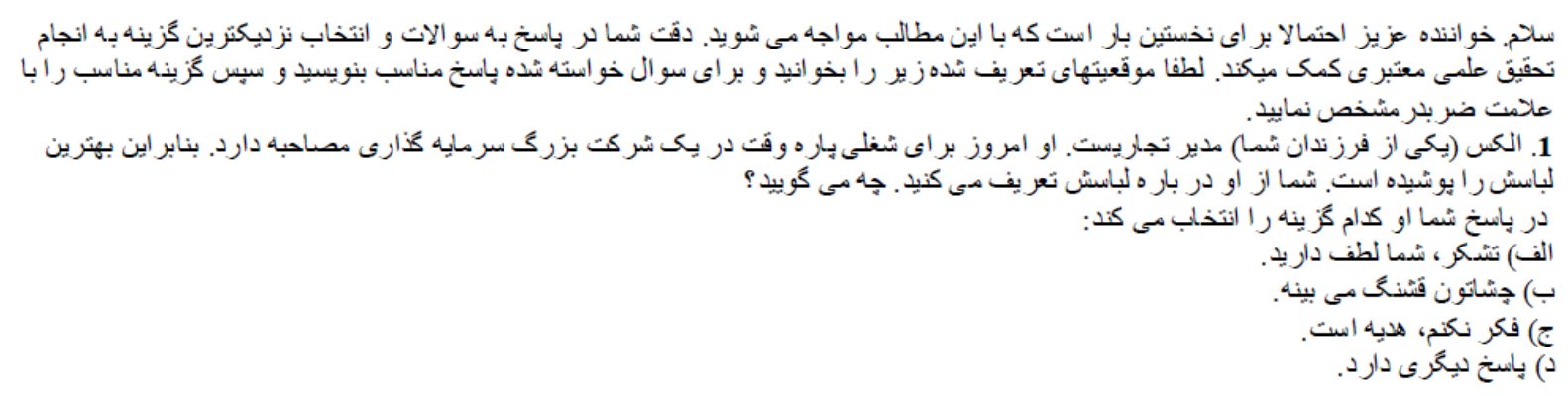




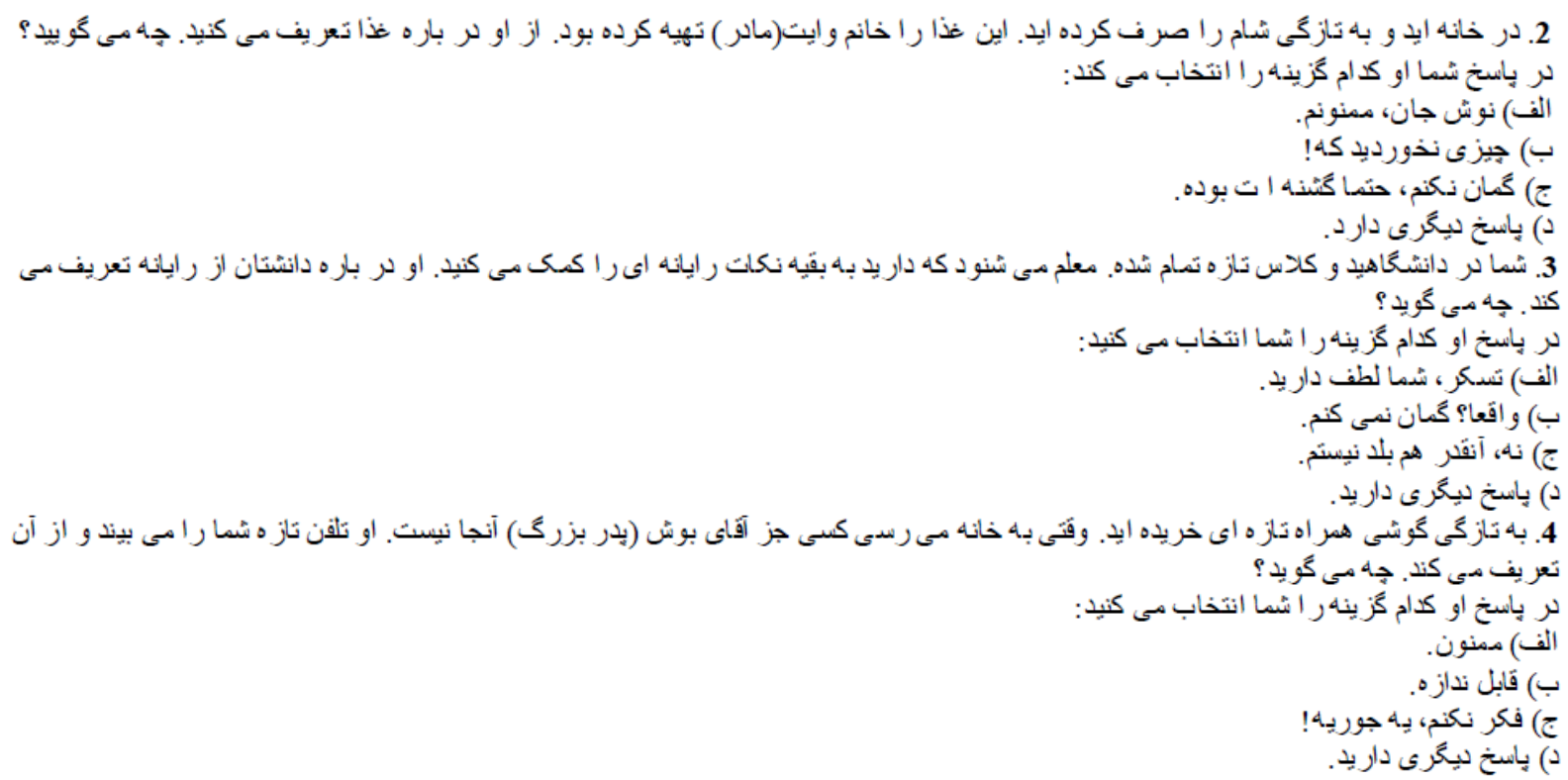




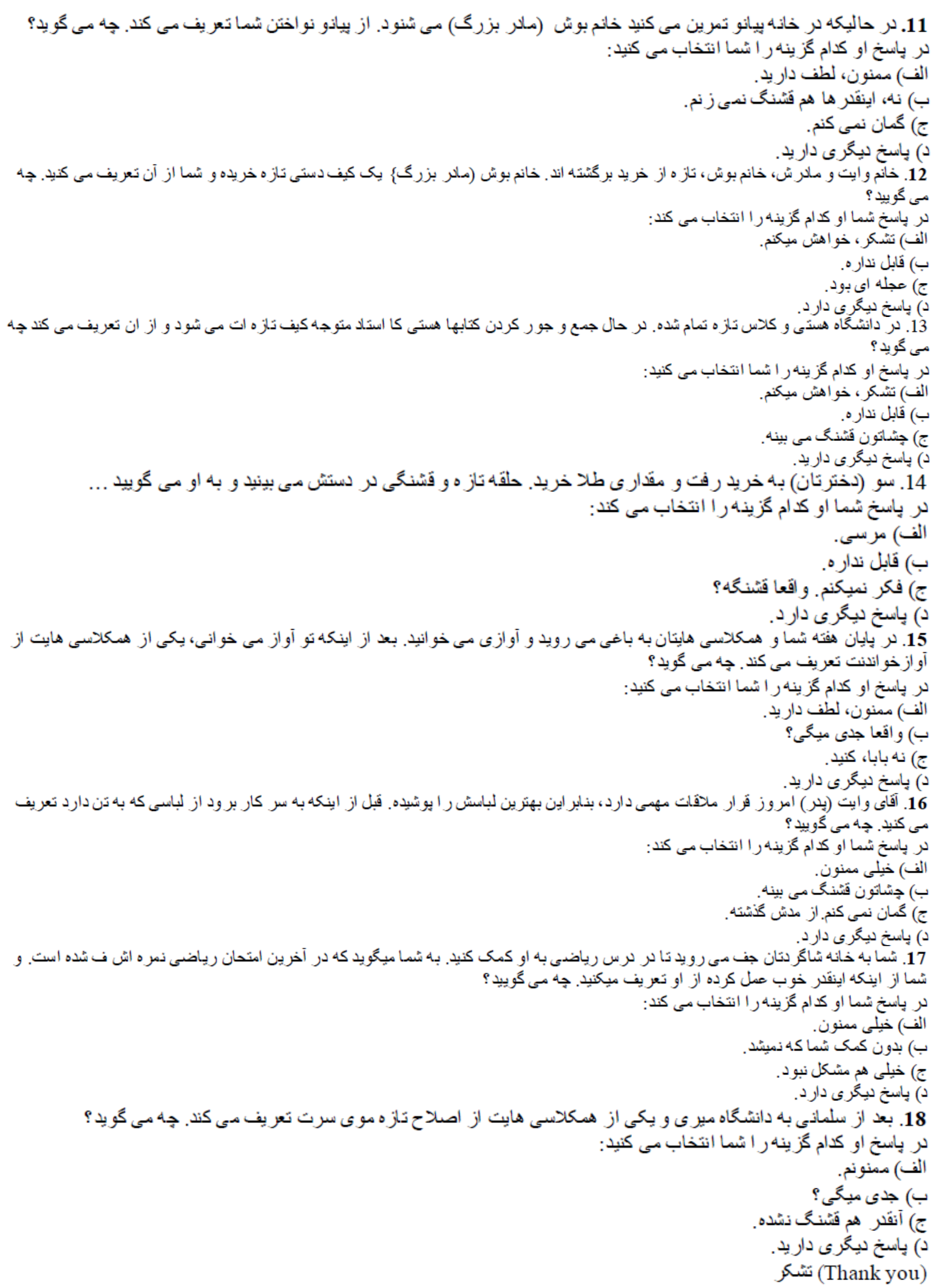

\section{REFERENCES}

[1] Bardovi-Harlig, K., and Griffin, R. (2005). L2 pragmatic awareness: Evidence from the ESL classroom. System 33, 401-415.

[2] Barnlund, D. C. \& Araki, S. (1985). Intercultural encounters: the management of compliments by Japanese and Americans. Journal of Cross-Cultural Psychology, 16 (1), 9-26.

[3] Billmyer, K. (1990a). The effect of formal instruction on the development of sociolinguistic competence: the performance of compliments. Unpublished doctoral dissertation, University Pennsylvania, Philadelphia. 
[4] Billmyer, K. (1990b). "I really like your lifestyle": ESL learners learning how to compliment. Penn Working Papers in Educational Linguistics, 6, 31-48.

[5] Billmyer, Kristine A. (1991). The effect of formal instruction on the development of sociolinguistic competence: The performance of compliments. Retrieved on June 12th,2011 from http://www.compliments

[6] Chen, R. (1993). Responding to compliments: A contrastive study of politeness strategies between American English and Chinese speakers. Journal of Pragmatics, 20, 49-75.

[7] Chung-hye Han. (1992). A comparative study of compliment responses: Korean females in Korean interactions and in English interactions. Working Papers in Educational Linguistics, 8 (2), 17-31.

[8] Creese, A. (1991). Speech act variation in British and American English. Penn Working Papers in Educational Linguistics, 7 (2), 37-58.

[9] Daikuhara, M. (1986). A study of compliments from a cross-cultural perspective: Japanese vs. American English. Working Papers in Educational Linguistics, 2 (2), 103-134.

[10] Furukawa, Y. (2000). "Home"no joukenni kansuru ichikousatsu ( 'An observation on conditions for compliments'). Nihongo nihon bunka keenkyuku (Research on the Japanese Language and Culture), 10, 117-130.

[11] Furukawa, Y. (2001). Gengo kinou dounyuueno ichi shian: "home"wo chuushinni ('Introducing linguistic functions: Compliments among other functions'). Nihongo nihon bunka kenkyuu, 11, 57-72.

[12] Holme, J. (1986). Compliments and compliment responses in New Zealand English. Anthropological Linguistics, $28,485-508$.

[13] Ishihara, N. (2003a). Giving and responding to compliments. In K. Bardovi-Harlig \& R. Mahan Taylor (Eds.), Teaching pragmatics. Washington DC: Office of English Programs, U.S. Department of State. Retrieved on November 28th , State.gov/education/engteaching/pragmatics.htm 2003, http://exchanges

[14] Ishihara, N.(2011), Formal instruction on the speech act of giving and responding to compliments. Proceedings of the 7th Conference of Pan-Pacific Association of Applied Linguistics, 62-78 Retrieved on June 10th 2011 from http://www. Instruction on compliments.

[15] Kasper, G., \& Rose, K. R. (2002). Pragmatic development in a second language. Language Learning 52: Supplement 1.

[16] Kasper, G. and Roever, C. (2005) 'Pragmatics in second language learning', in E. Hinkel(ed.), Handbook of Research into Second Language Teaching and Learning. London: Routledge.

[17] Koike, H. (2000). "Home"eno hentouni kansuru fukuji bunkateki hikaku: Taijan kankei betsu, seibetsu, sedaikan (Á comparative study of responses to compliment in terms of subcultures: Interpersonal relations, sex, and generations'). Shindhuu Daigaku Kyouiku Gakubu Kiyou (Journal of the Faculty of Education), 100, 47-55.

[18] Lorenzo-Dus, N. (2001). Compliment responses among British and Spanish university students: A contrastive study. Journal of Pragmatics, 33, 107-27.

[19] Manes, J. (1983). Compliments: A mirror of cultural values. In N. Wolfson \& E. Judd (Eds.), Sociolinguistics and language acquisition (pp. 96-102). New York: Newbury House.

[20] Manes, J. \& Wolfson, N. (1981). The compliment formula. In F. Coulmus (Ed.), Conversational routine: Explorations in standardized communication situations and prepatterned speech (pp. 115-132). The Hague: Mouton.

[21] Miles, P. (1994). Compliments and gender. University of Hawaii Occasional Papers Series, 26, 85-137.

[22] O'keeffe, A. et al. (2011). Introducing Pragmatics in Use. London: Routledge.

[23] Richards, Jack C. et al.(1997). New Interchange. Cambridge: Cambridge. University Press.

[24] Rose, K. R. and Kwai-fun, C. N. (2001). Pragmatic and grammatical awareness: A function of the learning environment. In K. R. Rose \& G. Kasper (2001), Pragmatics in Language teaching (pp. 145-170).

[25] Rose, Kenneth R, \& Kasper, Gabriele (2001). Pragmatics in Language Teaching (pp. 145-170). Cambridge, UK: Cambridge University Press.

[26] Schmidt, R. (1993).Consciousness, learning and interlanguage pragmatics. In G. Kasper \& S. Blum-Kulka (Eds.), Interlanguage Pragmatics (pp. 21042). Oxford: Oxford University Press.

[27] Takimoto, M. (2009) 'The effects of input-based tasks on the development of learners' pragmatic proficiency'. Applied Linguistics 30(1): 1-25.

[28] Teroa, R. (1996). Home ktobaeno hentou subairu ('Response styles to compliments). Nihongogaku (Japanese Linguistics), 5 , (5), 81-88.

[29] Wolfson, N.(1981a). Compliments in cross-cultural perspective. TESOL Quarterly, 15, 117-124.

[30] Wolfson, N. (1981b). Invitations, compliments and the competence of the native speaker. International Journal of Psychollinguistics, 8. 7-22.

[31] Wolfson, N. \& Manes, J. (1980). The compliments as a social strategy. Papers in Linguistics, 13, 389-410.

Zia Tajeddin is the head of the faculty of English Language and Literature at Allameh Tabataba'i University in Tehran, Iran from 2001and an associate professor of TEFL and Adjunct Professor and Postgraduate Committee Member of Sharif University of Technology. At present, he runs Discourse Analysis and Interlanguage(TEFL), Syllabus Design and Material Development(TEFL), Theories of Learning(TEFL) at Ph. D. level and Language Testing(TEFL), Syllabus Design and Mateial Development(TEFL), Theories of Second Language Acquisition: (Linguistics: Teaching Persian to the Speakers of Other Languages), Language Testing (Linguistics: Teaching Persian to the Speakers of Other Languages), Practical Teaching (Linguistics: Teaching Persian to the Speakers of Other Languages), Essay Writing (Translation Studies), Principles of Language Teaching(TEFL) and Teaching Language Skills(TEFL) at M. A. level at a number of universities including Allameh Tabataba'i University. Moreover, he has published many articles, written and translated many books, had many conference presentations, run some conference chairs, supervised many Ph. D. and M. A. Dissertations and Theses. Currently, he is Editor-in- Chief and Committee Member of many Journals and prominent Research Centers. 
Mohammad Reza Ghamari Received a B.A. in English Language and Literature from Shahid Beheshti University in Tehran and an M.A. in TEFL from the Islamic Azad University in Najafabad, in 2006. He is currently a Ph.D. student of TEFL at Allameh Tabatab'i University and a faculty member of Police University. As for his professional background, he has taught the English course at various universities. Moreover, he has published a few articles and 5 books. 